ARTICLE

\title{
Sea-ice retreat suggests re-organization of water mass transformation in the Nordic and Barents Seas
}

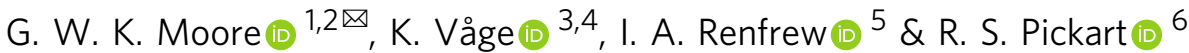

Water mass transformation in the Nordic and Barents Seas, triggered by air-sea heat fluxes, is an integral component of the Atlantic Meridional Overturning Circulation (AMOC). These regions are undergoing rapid warming, associated with a retreat in ice cover. Here we present an analysis covering 1950-2020 of the spatiotemporal variability of the air-sea heat fluxes along the region's boundary currents, where water mass transformation impacts are large. We find there is an increase in the air-sea heat fluxes along these currents that is a function of the currents' orientation relative to the axis of sea-ice change suggesting enhanced water mass transformation is occurring. Previous work has shown a reduction in heat fluxes in the interior of the Nordic Seas. As a result, a reorganization seems to be underway in where water mass transformation occurs, that needs to be considered when ascertaining how the AMOC will respond to a warming climate.

\footnotetext{
${ }^{1}$ Department of Physics, University of Toronto, Toronto, ON, Canada. ${ }^{2}$ Department of Chemical and Physical Sciences, University of Toronto Mississauga, Mississauga, ON, Canada. ${ }^{3}$ Geophysical Institute, University of Bergen, Bergen, Norway. ${ }^{4}$ Bjerknes Centre for Climate Research, Bergen, Norway. ${ }^{5}$ School of Environmental Sciences, University of East Anglia, Norwich, UK. ${ }^{6}$ Woods Hole Oceanographic Institution, Woods Hole, MA, USA.

凶email: gwk.moore@utoronto.ca
} 
T he northward transport of warm and salty water within the North Atlantic Ocean, emanating from the Gulf Stream system, plays a fundamental role in the Earth's climate ${ }^{1,2}$. The wintertime densification of this Atlantic Water, via the transfer of heat and moisture to the atmosphere as it passes through the Nordic (Norwegian, Greenland and Iceland) and Barents Seas, is an important contributor to the deep southward return flow of the $\mathrm{AMOC}^{1,3-5}$. This water mass modification produces Atlantic-origin overflow water along the rim current system encircling the Nordic Seas ${ }^{4}$. Atlantic Water also enters the Arctic Ocean through the east side of Fram Strait and the Barents $\mathrm{Sea}^{6,7}$ where it is further transformed ${ }^{8}$, impacting the thermohaline structure of the Arctic Ocean, as well as the distribution of sea ice ${ }^{9}$. Ultimately this modified Atlantic Water reenters the Nordic Seas through the west side of Fram Strait where it contributes to overflow waters crossing the Greenland-Scotland Ridge ${ }^{4,10-12}$. In addition, colder and fresher Arctic-origin overflow water is formed within the interior basins of the western Nordic Seas ${ }^{11,13,14}$. The regional air-sea interaction that is necessary for these water mass changes also impacts the atmosphere, through a warming and moistening of the atmospheric boundary layer ${ }^{15}$, as well as marine ecosystems ${ }^{16}$.

Within the Nordic and Barents Seas, there exist three major boundary currents where water mass modification occurs (Fig. 1): the East Greenland Current (EGC) that flows southward along the East Greenland shelfbreak/upper-slope from Fram Strait to Denmark Strait ${ }^{17,18}$; the Norwegian Atlantic Current that flows northward through Fram Strait into the Nansen Basin as the Svalbard Branch (SB) ${ }^{7,8}$; and the Barents Sea Branch (BSB) that progresses from the Norwegian Sea through the Barents Sea towards Novaya Zemlya ${ }^{6,19,20}$. These latter two branches merge in the Arctic Ocean to form the circumpolar Atlantic Water Boundary Current. Water mass modification also occurs throughout the central Nordic Seas within the Norwegian Sea's Lofoten Basin $^{21}$, as well as within the Iceland and Greenland Seas $3,10,13$. Both the EGC and SB flow along the shelfbreak and we used this characteristic to define the orientation of the domains for these currents (see Fig. 1); for the BSB the domain was defined based on the representation of its spatial extent ${ }^{22}$. For all three currents, we assume a width of $100 \mathrm{~km}$ (results were not sensitive to this width).

In the Nordic and Barents Seas, there is evidence of multidecadal variability in winter ice $\operatorname{cover}^{23}$ that includes a significant expansion off East Greenland during the late 1960s and early 1970 s, the so-called ice years ${ }^{24}$. More recently, there has been a sustained retreat of sea ice that has resulted in the disappearance of the Greenland Sea's Odden Ice Tongue ${ }^{25}$, as well as reductions in ice cover across the northern and eastern parts of the Barents $\mathrm{Sea}^{26}$ and to the north of Svalbard ${ }^{27}$.

This retreat appears to be resulting in a reduction in air-sea interaction over the central Iceland and Greenland Seas that may be lessening the production of dense overflow waters there ${ }^{10,28}$. At the same time, this sea-ice retreat is exposing part of the EGC to the atmosphere, leading to enhanced air-sea interaction in that region ${ }^{29}$. Within the Barents Sea, the retreat of winter sea ice has resulted in profound changes in the climate-an Atlantification of the region ${ }^{30}$.

In this paper, we focus on the surface turbulent heat flux, which is the sum of the surface sensible and latent heat fluxes, with the convention being that fluxes out of the ocean are positive. This flux plays a dominant role in the high-latitude water mass transformation $3,31,32$. Please see the "Methods" section for additional details. Here we show that there is an increase in the air-sea heat fluxes along these currents that is a function of the currents' orientation relative to the axis of sea-ice change suggesting enhanced water mass transformation is occurring

\section{Results}

Spatiotemporal variability in the air-sea heat fluxes and seaice. Figure 2 shows the spatiotemporal variability in the winter mean surface turbulent heat flux and sea-ice extent for decadal means between 1950 and 2020. The winter mean turbulent heat flux is typically small over ice covered regions, as a result of the insulating properties of sea ice, and increases rapidly across the marginal ice zones with maxima in the northern Greenland Sea, in the vicinity of Svalbard, as well as in the Barents Sea ${ }^{10,28,33}$. There are also minima in the Iceland and Greenland Seas that are the result of the competing influences of the two climatological

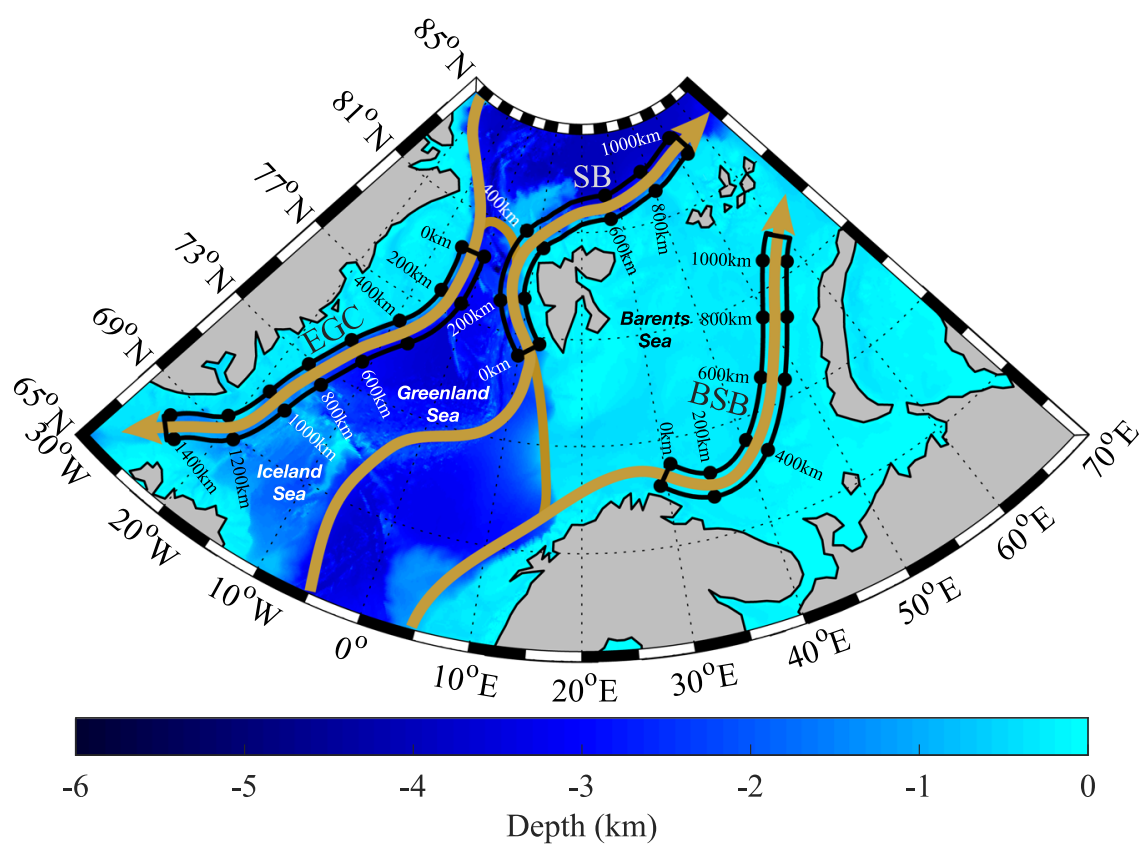

Fig. 1 The bathymetry of the Nordic and Barents Seas. The domains associated with the East Greenland Current (EGC), the Svalbard Branch (SB), and the Barents Sea Branch (BSB) are shown in black with distances along the direction of the current flow indicated. 

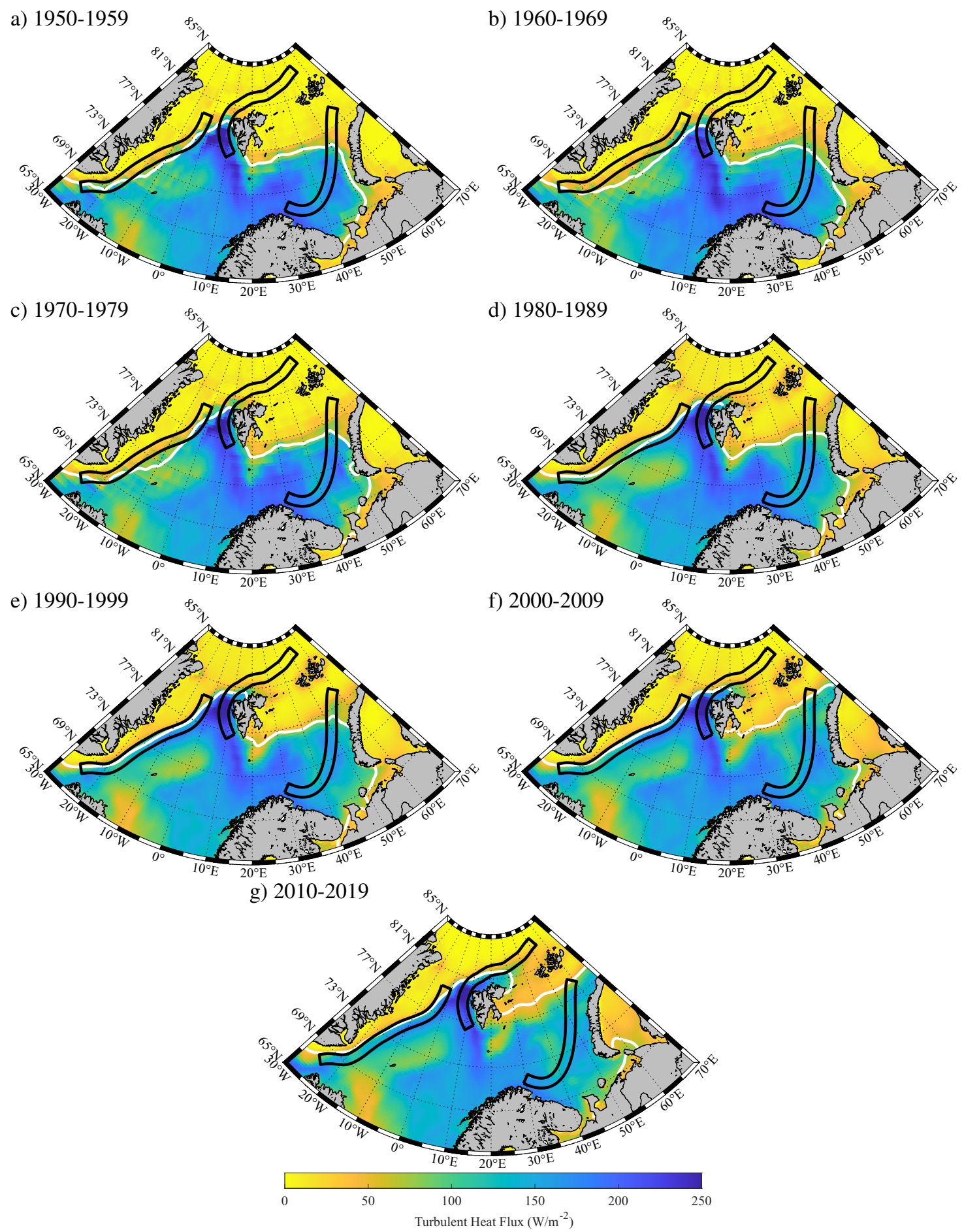

Fig. 2 Spatiotemporal variability in winter mean turbulent heat flux over the Nordic and Barents Seas. Decadal means, a-g, are shown for the period 1950-2020. The domains associated with the East Greenland Current (EGC), the Svalbard Branch (SB), and the Barents Sea Branch (BSB) are shown in black. The $50 \%$ sea ice concentration contour is shown in white. All fields are from the ERA5 Reanalysis.

low-pressure systems, the Icelandic and Lofoten Lows, that are prevalent in the region during winter ${ }^{33}$.

The variability in ice cover clearly modulates the winter-mean turbulent heat flux along the EGC, the SB, and the BSB. For example, in the Greenland Sea, an expansion of ice cover during the 1960s and its subsequent retreat over the following decades corresponds with a movement of the region of enhanced heat fluxes relative to the EGC, which is dynamically tied to the shelfbreak and upper slope along east Greenland ${ }^{17}$. Over both the
Barents Sea and the region north of Svalbard, the retreat of sea ice has resulted in changes in the turbulent heat fluxes along the SB and the BSB currents.

Along-current variability in the air-sea heat fluxes and sea-ice. To quantify these changes, decadal means of the along-current turbulent heat flux and sea ice concentration were constructed (Fig. 3). Over the EGC (Fig. 3a), there was a pronounced jump in 

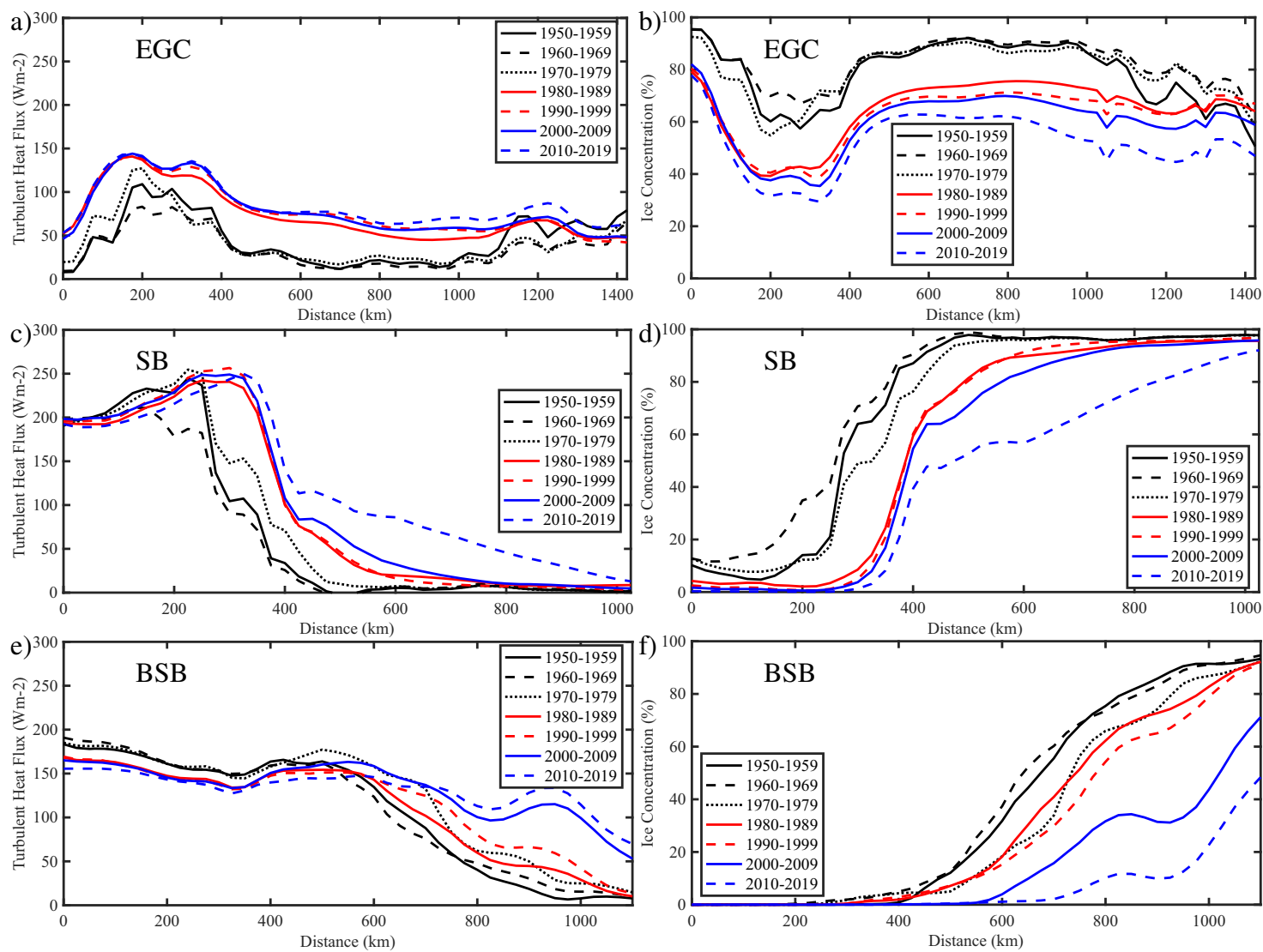

Fig. 3 Evolution of the along-current winter mean turbulent heat flux and ice concentration. Decadal means, $\mathbf{a}, \mathbf{c}$, and $\mathbf{e}$ for the turbulent heat flux and b, $\mathbf{d}$ and $\mathbf{f}$ for the ice concentration, are shown for the period 1950-2020. Results are shown for the East Greenland Current (EGC), the Svalbard Branch (SB), and the Barents Sea Branch (BSB). All fields are from the ERA5 Reanalysis.

the magnitude of the turbulent heat fluxes between the 1970s and 1980s. This was most noticeable along the middle of the EGC, from approximately 400 to $1100 \mathrm{~km}$, where the increase was relatively uniform due to the retreat of sea ice being perpendicular to the current (c.f. Fig. 2). Prior to this transition, the turbulent heat fluxes were low, reaching a minimum during the ice years of the 1960/1970s. After this breakpoint, the fluxes were considerably larger along this centre section and showed only small changes with time. The situation at the northern and southern ends of the EGC was more complicated. At the northern end (i.e., small distances along the current), there was large variability in heat fluxes in the 1950s to 1970 s, due to associated variability in sea-ice concentration (Fig. 3b). After this period, a significant retreat in sea-ice has limited the variability from the 1980 s-2010s (Fig. 3b). At the southern end (i.e., large distances along the current), there has been high variability in heat fluxes and sea ice across the entire period.

The character of the turbulent heat flux along the SB (Fig. 3c) and BSB (Fig. 3e) are considerably different. Along both currents, the distance subject to high heat fluxes has increased through the decades. For the SB, the flux increase was largest between 250 and $600 \mathrm{~km}$ along the current, while for the BSB, the flux increase was largest between 600 and $1100 \mathrm{~km}$. For both currents, this was due to a retreat of sea-ice cover, primarily in the same direction as the currents (Fig. 3d, f). There were differences in the timing of the largest changes in the heat fluxes. For the SB, this occurred during the 2000s; while for the BSB, the changes have been more uniform over time. At the southern end of both currents, there was a trend towards lower heat fluxes which was the result of a warmer and moister atmosphere there ${ }^{28}$.
Sea-ice retreat is instrumental to the changes in surface heat fluxes along all three currents. However, it is clear that the orientation of the current relative to the direction of sea-ice retreat is crucial in how the changes are manifested. For the EGC, the orientation of the current is approximately perpendicular to the direction of sea-ice retreat leading to changes in heat fluxes along the length of the current, while for the SB and BSB the currents are aligned with the direction of sea-ice retreat leading to changes in heat fluxes in focused regions.

Along-current changes to the air-sea heat fluxes. Although the decadal means shown in Figs. 2 and 3 confirm that there is significant spatiotemporal variability in the heat fluxes along the three current systems, there is an arbitrariness to the decadal timescale used. A more flexible representation of this variability comes from Hovmöller plots of the turbulent heat flux anomaly (Fig. 4). For the EGC (Fig. 4a), one can see the large change in the heat flux that occurred after the ice years of the late 1960s and early 1970 s and the characteristic that interannual variability often affects the entire length of the EGC. Along the SB (Fig. 4b), the evolution of the heat flux anomaly was quite different. Prior to the 1980s, the anomalies had a dipolar structure with positive anomalies to the west of Svalbard (i.e., distances less than $300 \mathrm{~km}$ ) and negative anomalies to the north. After the 1980s, the sign of the dipole reversed with the region of positive values extending northeastward in recent years. A dipolar structure is also present along the BSB (Fig. 4c) with again a reversal in the sign of the anomalies around 1980.

The results presented so far indicate that there is complexity in the distribution of the heat fluxes along the three current systems 

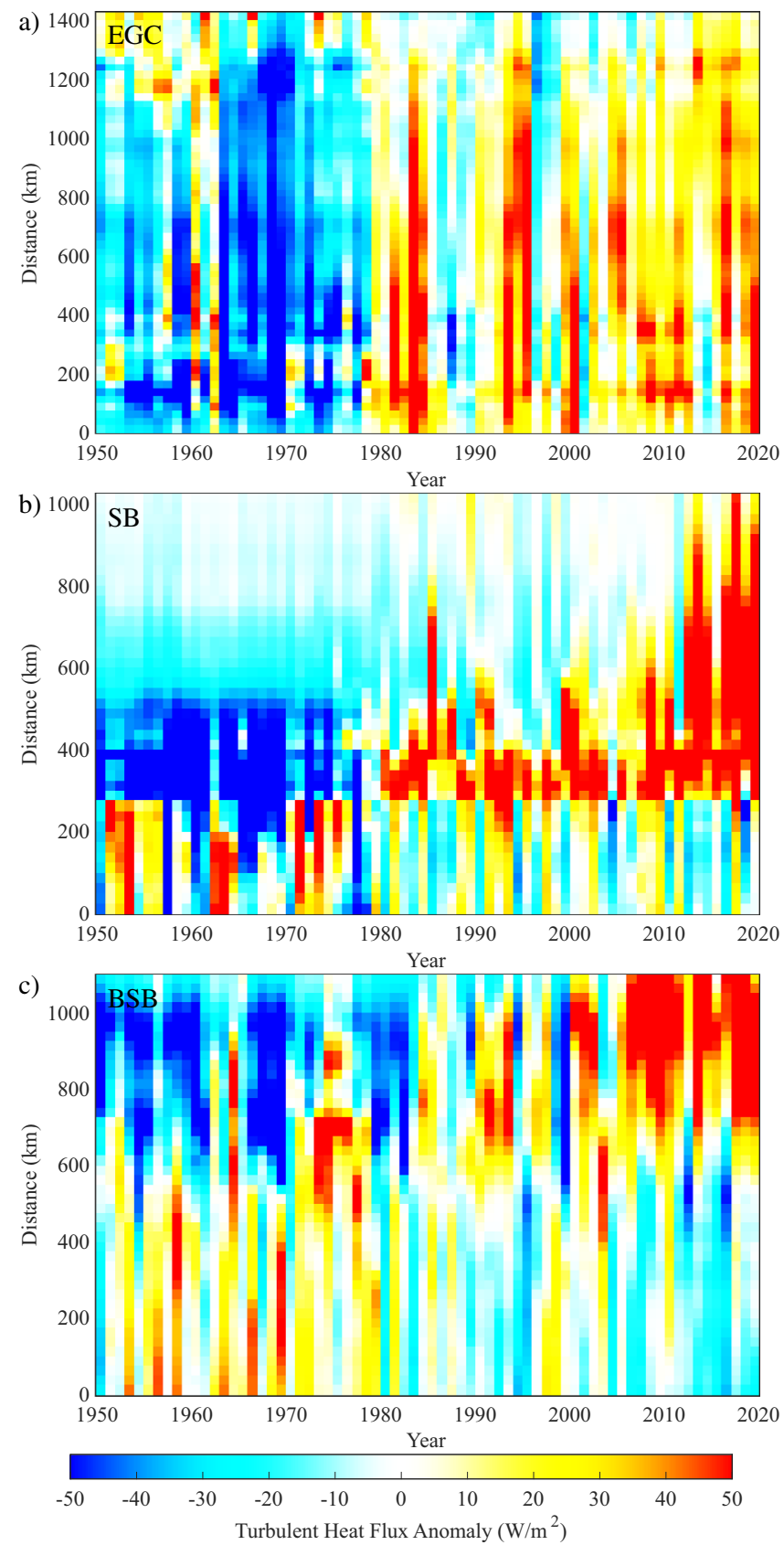

Fig. 4 Hovmöller plots illustrating turbulent heat flux anomaly along the current domains. Panels are for the: a East Greenland Current (EGC); b Svalbard Branch (SB) and c Barents Sea Branch (BSB). The anomaly is defined as the difference with respect to the mean from 1950 to 2020. All fields are from the ERA5 Reanalysis.

(Fig. 3 and Supplementary Fig. 1). As noted, the differing orientation of the current systems relative to the direction along which the changes in sea ice were largest is critical. For the EGC, the step-function-like change in the heat fluxes along the entire current is the result of its orientation being normal to the direction along which ice has advanced then retreated. In contrast, for both the SB and BSB the striking reversals in sign of the heat flux anomalies are the result of the sea-ice generally retreating in the direction of the currents.

Temporal variability of the along-current integrated air-sea heat fluxes. The along-current integrated heat flux, which quantifies the heat relinquished to the atmosphere, is a critical factor in the transformation of the water masses advected by the currents. Figure 5 shows the time series of the winter-mean heat flux averaged along the three current systems, as well as moving window trends with a variable start date and a fixed end date of 2020. The statistical significance of the trends is assessed using a Monte Carlo technique that uses 10,000 synthetic time series generated so as to retain the spectral characteristics of the underlying time series, thereby retaining any temporal autocorrelation that may reduce the degrees of freedom ${ }^{28}$.

For the EGC (Fig. 5a), the minimum in heat fluxes during the 1960s is evident, as well as the step-function-like increase in heat fluxes that occurred after this minimum. Indeed, the decadal mean for the ice years period $1965-1974$ was $26 \mathrm{~W} / \mathrm{m}^{2}$, half the $52 \mathrm{~W} / \mathrm{m}^{2}$ of the preceding 10 -year period (1955-1964) and only a third of the $75 \mathrm{~W} / \mathrm{m}^{2}$ of the following 10 -year period (1974-1984). The changes across each of these periods are statistically significant at the 95th percentile confidence level. The maxima in heat fluxes during the mid 1980s and 1990s stand out as well. The moving window trend for the EGC (Fig. 5b) increases for start dates up to the mid 1960s reaching a maximum of $\sim 12 \mathrm{~W} / \mathrm{m}^{2} /$ decade that reflects the low heat fluxes during the ice years. After this time, the trend in the EGC winter mean heat flux is reduced by approximately $50 \%$ and is no longer statistically significant at the 95th percentile confidence level. The magnitude of the trend increases attaining values above $10 \mathrm{~W} / \mathrm{m}^{2} /$ decade for start dates after 1990 but they do not reach statistical significance. Over the period from 1950 to 2020, the winter mean heat flux averaged along the EGC increased from $\sim 50$ to $\sim 100 \mathrm{~W} / \mathrm{m}^{2}$, statistically significant at the 99th percentile confidence interval.

For the SB (Fig. 5c), the winter mean heat fluxes underwent a sustained increase after the 1960s that accelerated after 2000. The moving window trend of $\sim 10 \mathrm{~W} / \mathrm{m}^{2} /$ decade during much of this period is statistically significant and increases to $\sim 20 \mathrm{~W} / \mathrm{m}^{2} /$ decade for start dates after the mid 1990s, when it is also statistically significant, see (Fig. 5d). Over the period from 1950 to 2020, the winter mean heat flux averaged along the SB increased from $\sim 75$ to $\sim 130 \mathrm{~W} / \mathrm{m}^{2}$, statistically significant at the 99th percentile confidence interval.

For the BSB (Fig. 5e), there is significant inter-annual variability throughout the period, but no evidence of the decadal variability seen in the EGC or SB. Rather, there was a sustained increase in the winter mean heat flux averaged along this current from $\sim 120 \mathrm{~W} / \mathrm{m}^{2}$ during the 1950 s to $\sim 140 \mathrm{~W} / \mathrm{m}^{2}$ during the 2010s. This relatively modest increase in integrated flux is because of the dipolar nature (Fig. 4c) of the anomalies along the current. This is confirmed by a moving window trend for this time series of $4-10 \mathrm{~W} / \mathrm{m}^{2} /$ decade for start dates from the $1950 \mathrm{~s}-1990 \mathrm{~s}$ (Fig. 5f).

\section{Discussion}

These results confirm that the relative orientation of sea-ice retreat versus the current axis is critical for characterizing the changes in the surface heat fluxes. In particular, the large increase observed along the EGC is due to this current being perpendicular to the axis of sea ice retreat and therefore the entire current system is being exposed to the atmosphere at once. By contrast, for the SB and BSB the currents are parallel to the axis of sea-ice retreat resulting in dipolar changes along their length that reduces the magnitude of integrated heat flux.

The trends in turbulent heat flux along these three boundary currents are primarily a response to sea-ice retreat, although an element of differential warming between the atmosphere and ocean is also contributing (Supplementary Fig. 2). We have examined trends in the inflow of warm Atlantic water into the 

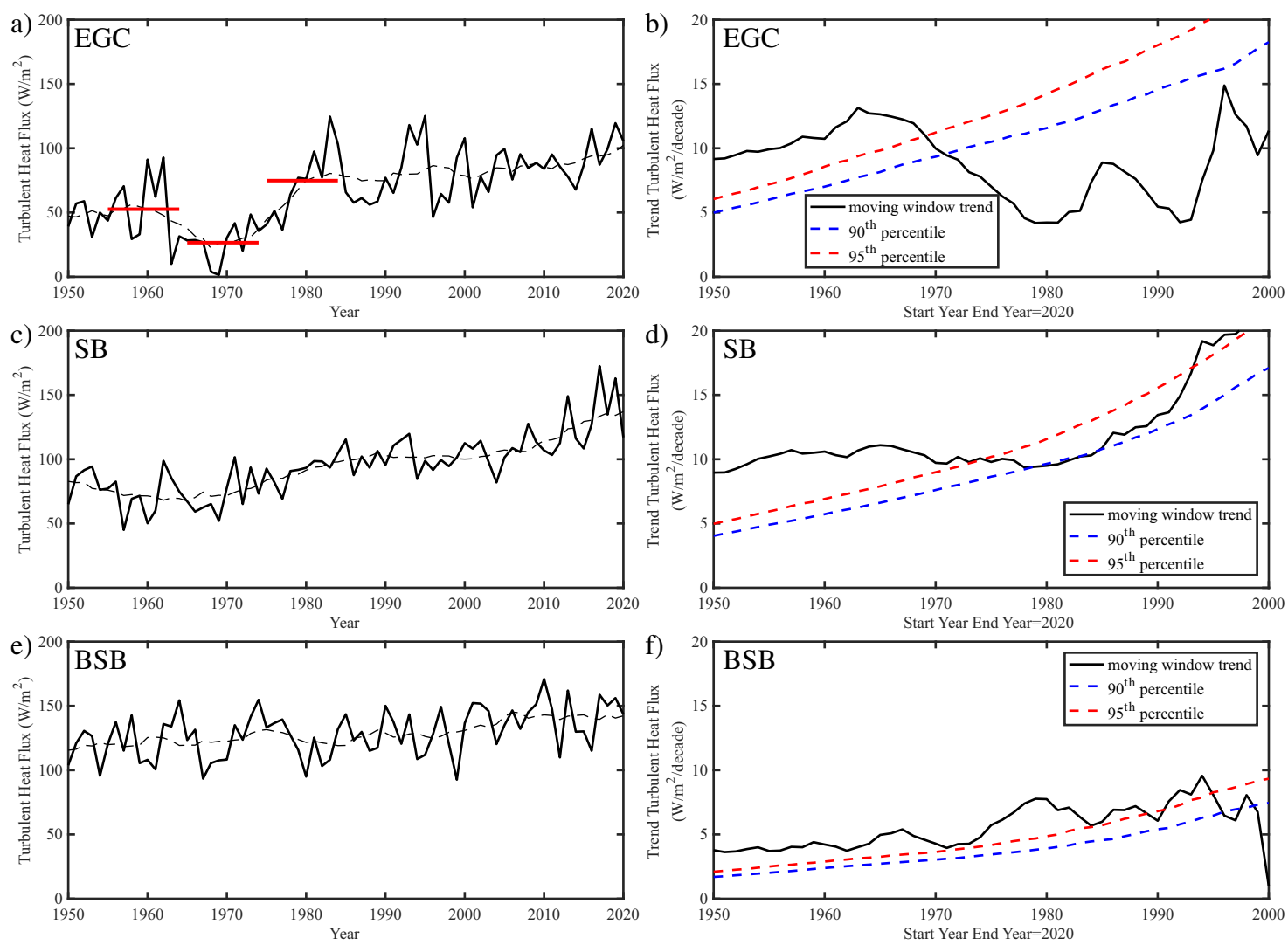

Fig. 5 Temporal variability in along-current averaged winter mean turbulent heat flux. Time series of the turbulent heat flux are shown in the black curves for the: a East Greenland Current (EGC); b Svalbard Branch (SB) and e Barents Sea Branch (BSB) with the corresponding black dashed curves representing the low frequency variability as expressed by a 10-year moving window average. In a the decadal means over the period before (1955-1964), during (1965-1974) and after (1975-1984) the ice years are shown by the red lines. The trend in the winter turbulent heat flux are shown in the black curves as a function of a variable start year with a fixed end year of 2020 for the: $\mathbf{b}$ EGC, $\mathbf{d}$ SB and $\mathbf{f}$ BSB with the corresponding blue and red dashed curves representing the 90th and 95th percentile trends from a Monte Carlo distribution of time series that share the same spectral characteristics as the underlying time series. Trends with magnitudes larger than a given percentile curve are statistically significant at that threshold. All fields are from the ERA5 Reanalysis.

Nordic Seas using observations ${ }^{34}$ and find these are dwarfed by the trends in atmospheric temperature (Supplementary Fig. 3). The surface wind speed also plays a role in air-sea heat fluxes; however, the changes in wind speed over the Nordic Seas have been small ${ }^{28}$. The changing nature of water mass transformation in the Greenland and Iceland Sea gyres has been previously examined $^{28}$. However, as that was a diagnostic study based on reanalysis data, they could not determine which mechanism was dominant. A recent analysis of control and global warming coupled model simulations for the region has found that sea-ice retreat dominates the surface heat flux change, although this is modulated by an increase in the northward transport of warm water ${ }^{35}$.

If sea-ice retreat is the dominant factor, then the recent changes experienced by these boundary currents will follow the evolution of the wintertime sea ice distribution. Once the wintertime sea ice has permanently retreated from a region, the differential warming of the atmosphere and ocean will lead to a decrease in the air-sea heat fluxes-as already evident along the southern sections of SB and BSB (Figs. 3, 4). Indeed, we would anticipate these reduced fluxes will extend northward over time. However, a key point is that once the boundary current is ice-free in winter, water mass transformation may occur directly within the current-if the surface fluxes are sufficiently strong such as occurs during cold air outbreaks in other regions, e.g., the Irminger and Labrador Seas $^{31,36}$.
Previous work ${ }^{28}$ has shown that a trend towards lower heat fluxes within the Greenland and Iceland Sea gyres is leading to shallower oceanic mixed-layers and diminished volumes of overturned waters in the interior. This has the potential to reduce the ventilation of intermediate waters and the supply of dense overflow waters to the North Atlantic. In contrast, we have shown here that sea-ice retreat and the associated increase in heat fluxes along the boundary currents of this region has the potential to increase ventilation of intermediate waters and densify the Atlantic-origin overflow water being transported by these currents, as recently observed along the southern $\mathrm{EGC}^{29}$ and the $\mathrm{SB}^{8}$.

Since waters transformed within the boundary currents are readily transported to the overflows out of the Nordic Seas, this shift in the location of water mass transformation from the interior to the boundary has potentially profound implications for the lower limb of the AMOC-keeping in mind that a large contribution to the AMOC comes from the transformation occurring in the Nordic Seas ${ }^{32}$. Recent work ${ }^{37,38}$ indicates a slowdown of the AMOC over the last century. However, the enhanced boundary current transformation implicated in this study has the potential to impart resilience to the overturning north of the Greenland-Scotland Ridge which may help maintain the AMOC in a warming climate. Increased densification of this water should in fact lead to enhanced entrainment of ambient fluid as the dense water spills over the ridge ${ }^{39}$, which means more sinking. Further work is clearly required to document the large- 
scale impacts of wintertime ice retreat from the continental margins of the Nordic and Barents Seas.

\section{Methods}

The documented variability in ice cover motivates an examination of the spatiotemporal variability of air-sea heat fluxes along these boundary currents. To accomplish this, the 5th generation reanalysis from the European Centre for Medium-Range Forecasts (ECMWF) known as ERA5 was used ${ }^{40}$. Both ERA5 and the well-established 4th generation reanalysis known as ERA-Interim ${ }^{41}$ are based on ECMWF's Integrated Forecast System (IFS). The ERA5 data have a spatial resolution of $\sim 30 \mathrm{~km}$ and cover the period 1950-onwards, which includes the recently released early-period extension. The sea surface temperature in ERA5 is a prescribed field that is a blend of a number of products from the UK Met Office and others ${ }^{40}$. In ice-covered regions, where observations are limited, the sea surface temperature is a regressed function of the sea ice concentration ${ }^{42}$.

It should be noted that the present study neglects the impact of precipitation and evaporation on the surface salinity (although evaporation is considered as it relates to the latent heat flux). This is because a number of studies have indicated that evaporation and precipitation over the region of interest are, on seasonal timescales, in balance ${ }^{43,44}$ resulting in only small changes to the surface density ${ }^{31,45}$. Freshwater fluxes from terrestrial sources are also neglected. While this could have relevance for the EGC due to its proximity to Greenland's melting ice sheet ${ }^{46}$, it has been suggested ${ }^{29}$ that there is substantial Ekman transport associated with the strong northerly barrier flow during the fall and winter along the East Greenland coast that keeps this freshwater on the shelf, thereby limiting its impact on the EGC. A recent modelling study confirmed this scenario ${ }^{47}$. We also neglect a number of oceanographic and cryospheric processes that can have impacts on water mass modification along these currents $\mathrm{s}^{5,48}$.

A comparison with in situ observations indicates that IFS-based reanalyses are able to represent the air-sea fluxes in these subpolar seas with a good degree of fidelity ${ }^{49-51}$. The complex spatial heterogeneity of the marginal ice zone leads to mesoscale variability ${ }^{2}$ that is not fully captured in reanalysis datasets that blend the open ocean and ice-covered fluxes in these regions ${ }^{51,53}$. To assess the impact of this uncertainty, a number of sensitivity tests were performed where the ERA5 air -sea heat fluxes in nearby ice-covered regions were merged with those from the COARE bulk flux parameterization to represent the heat flux over the open ocean regions of the marginal ice zone as a function of ice concentration. These tests provided sufficient confidence in the ERA5 air-sea heat fluxes within the marginal ice zone for this study.

\section{Data availability}

The ERA5 Reanalysis data used in this paper is available from the Copernicus Climate Data Store at: https://cds.climate.copernicus.eu/.

Received: 9 April 2021; Accepted: 23 November 2021; Published online: 10 January 2022

\section{References}

1. Rhines, P., Häkkinen, S. \& Josey, S. A. in Arctic-Subarctic Ocean Fluxes: Defining the Role of the Northern Seas in Climate (eds Dickson, R.R., Meincke, J., \& Rhines, P.) 87-109 (Springer Netherlands, 2008).

2. Kuhlbrodt, T. et al. On the driving processes of the Atlantic meridional overturning circulation. Rev. Geophys. 45, 1-32 (2007).

3. Marshall, J. \& Schott, F. Open-ocean convection: Observations, theory, and models. Rev. Geophys. 37, 1-64 (1999).

4. Mauritzen, C. Production of dense overflow waters feeding the North Atlantic across the Greenland-Scotland Ridge.1. Evidence for a revised circulation scheme. Deep-Sea Res. Part I-Oceanographic Res. Pap. 43, 769-806 (1996).

5. Tsubouchi, T. et al. Increased ocean heat transport into the Nordic Seas and Arctic Ocean over the period 1993-2016. Nat. Clim. Change 11, 21-26 (2021).

6. Smedsrud, L. H. et al. The role of the Barents Sea in the Arctic climate system. Rev. Geophys. 51, 415-449 (2013).

7. Våge, K. et al. The Atlantic Water boundary current in the Nansen Basin: Transport and mechanisms of lateral exchange. J. Geophys. Res.: Oceans 121, 6946-6960 (2016).

8. Pérez-Hernández, M. D. et al. Structure, transport, and seasonality of the Atlantic Water Boundary Current North of Svalbard: Results from a yearlong mooring array. J. Geophys. Res.: Oceans 124, 1679-1698 (2019).

9. Rudels, B. Arctic Ocean circulation and variability-advection and external forcing encounter constraints and local processes. Ocean Sci. 8, 261-286 (2012).

10. Våge, K., Moore, G. W. K., Jónsson, S. \& Valdimarsson, H. Water mass transformation in the Iceland Sea. Deep Sea Res. Part I: Oceanographic Res. Pap. 101, 98-109 (2015).
11. Våge, K. et al. Significant role of the North Icelandic Jet in the formation of Denmark Strait overflow water. Nat. Geosci. 4, 723 (2011).

12. Harden, B. E. et al. Upstream sources of the Denmark Strait Overflow: Observations from a high-resolution mooring array. Deep Sea Res. Part I: Oceanographic Res. Pap. 112, 94-112 (2016).

13. Brakstad, A., Våge, K., Håvik, L. \& Moore, G. W. K. Water mass transformation in the Greenland Sea during the period 1986-2016. J. Phys. Oceanogr. 49, 121-140 (2019).

14. Swift, J. H. \& Aagaard, K. Seasonal transitions and water mass formation in the Iceland and Greenland Seas. Deep Sea Res. Part A. Oceanographic Res. Pap. 28, 1107-1129 (1981).

15. Renfrew, I. A. et al. The Iceland Greenland Seas project. Bull. Am. Meteorological Soc. 100, 1795-1817 (2019).

16. Loeng, H. \& Drinkwater, K. An overview of the ecosystems of the Barents and Norwegian Seas and their response to climate variability. Deep-Sea Res. Part II-Topical Stud. Oceanogr. 54, 2478-2500 (2007).

17. Håvik, L. et al. Evolution of the East Greenland current from Fram Strait to Denmark Strait: synoptic measurements from summer 2012. J. Geophys. Res.: Oceans 122, 1974-1994 (2017).

18. Rudels, B., Fahrbach, E., Meincke, J., Budéus, G. \& Eriksson, P. The East Greenland Current and its contribution to the Denmark Strait overflow. ICES J. Mar. Sci. 59, 1133-1154 (2002).

19. Sandø, A. B., Nilsen, J., Gao, Y. \& Lohmann, K. Importance of heat transport and local air-sea heat fluxes for Barents Sea climate variability. J. Geophys. Res.: Oceans 115, 1-11 (2010).

20. Skagseth, $\varnothing$. et al. Reduced efficiency of the Barents Sea cooling machine. Nat. Clim. Change 10, 661-666 (2020).

21. Richards, C. G. \& Straneo, F. Observations of water mass transformation and Eddies in the Lofoten Basin of the Nordic Seas. J. Phys. Oceanogr. 45, 1735-1756 (2015).

22. Lien, V. S., Schlichtholz, P., Skagseth, $\varnothing . \&$ Vikebø, F. B. Wind-driven Atlantic water flow as a direct mode for reduced Barents Sea ice cover. J. Clim. 30, 803-812 (2017).

23. Mysak, L. A., Manak, D. K. \& Marsden, R. F. Sea-ice anomalies observed in the Greenland and Labrador Seas during 1901-1984 and their relation to an interdecadal Arctic climate cycle. Clim. Dyn. 5, 111-133 (1990).

24. Malmberg, S.-A. \& Valdimarsson, H. in ICES Marine Science Symposia 50-60, International Council for the Exploration of the Sea (ICES).

25. Comiso, J. C., Wadhams, P., Pedersen, L. T. \& Gersten, R. A. Seasonal and interannual variability of the Odden ice tongue and a study of environmental effects. J. Geophys. Res.-Oceans 106, 9093-9116 (2001).

26. Onarheim, I. H. \& Årthun, M. Toward an ice-free Barents Sea. Geophys. Res. Lett. 44, 8387-8395 (2017).

27. Onarheim, I. H., Smedsrud, L. H., Ingvaldsen, R. B. \& Nilsen, F. Loss of sea ice during winter north of Svalbard. Tellus A: Dyn. Meteorol. Oceanogr. 66, 23933 (2014).

28. Moore, G. W. K., Våge, K., Pickart, R. S. \& Renfrew, I. A. Decreasing intensity of open-ocean convection in the Greenland and Iceland seas. Nat. Clim. Change 5, 877 (2015).

29. Våge, K., Papritz, L., Håvik, L., Spall, M. A. \& Moore, G. W. K. Ocean convection linked to the recent ice edge retreat along east Greenland. Nat. Commun. 9, 1287 (2018).

30. Arthun, M., Eldevik, T., Smedsrud, L. H., Skagseth, O. \& Ingvaldsen, R. B. Quantifying the influence of Atlantic heat on Barents Sea ice variability and retreat. J. Clim. 25, 4736-4743 (2012).

31. Sathiyamoorthy, S. \& Moore, G. W. K. Buoyancy flux at ocean weather station Bravo. J. Phys. Oceanogr. 32, 458-474 (2002).

32. Chafik, L. \& Rossby, T. Volume, heat, and freshwater divergences in the subpolar North Atlantic suggest the Nordic Seas as key to the state of the meridional overturning circulation. Geophys. Res. Lett. 46, 4799-4808 (2019).

33. Moore, G. W. K., Renfrew, I. A. \& Pickart, R. S. Spatial distribution of air-sea heat fluxes over the sub-polar North Atlantic Ocean. Geophys. Res. Lett. https://doi.org/10.1029/2012GL053097 (2012).

34. ICES. ICES Report on Ocean Climate (ICES Cooperative Research Report, 2019).

35. Wu, Y., Stevens, D. P., Renfrew, I. A. \& Zhai, X. The response of the Nordic Seas to wintertime sea-ice retreat. J. Climate 34, 6041-6056 (2021).

36. Josey, S., de Jong, M., Oltmanns, M., Moore, G. W. K. \& Weller, R. Extreme variability in Irminger Sea winter heat loss revealed by ocean observatories initiative mooring and the ERA5 reanalysis. Geophys. Res. Lett. 46, 293-302 (2019).

37. Caesar, L., McCarthy, G., Thornalley, D., Cahill, N. \& Rahmstorf, S. Current Atlantic meridional overturning circulation weakest in last millennium. Nat. Geosci. 14, 1-3 (2021).

38. Caesar, L., Rahmstorf, S., Robinson, A., Feulner, G. \& Saba, V. Observed fingerprint of a weakening Atlantic Ocean overturning circulation. Nature 556, 191-196 (2018). 
39. Price, J. F. \& Baringer, M. O. N. Outflows and deep water production by marginal seas. Prog. Oceanogr. 33, 161-200 (1994).

40. Hersbach, H. et al. The ERA5 global reanalysis. Q. J. R. Meteorol. Soc. 146, 1999-2049 (2020).

41. Dee, D. P. et al. The ERA-Interim reanalysis: configuration and performance of the data assimilation system. Q. J. R. Meteorol. Soc. 137, 553-597 (2011).

42. Rayner, N. A. et al. Global analyses of sea surface temperature, sea ice, and night marine air temperature since the late nineteenth century. J. Geophys. Res.: Atmos. https://doi.org/10.1029/2002JD002670 (2003).

43. Schmitt, R. W., Bogden, P. S. \& Dorman, C. E. Evaporation minus precipitation and density fluxes for the North Atlantic. J. Phys. Oceanogr. 19, 1208-1221 (1989).

44. Walsh, J. E. \& Portis, D. H. Variations of precipitation and evaporation over the North Atlantic Ocean, 1958-1997. J. Geophys. Res.: Atmos. 104, 16613-16631 (1999).

45. Moore, G. W. K., Alverson, K. \& Renfrew, I. A. A reconstruction of the air-sea interaction associated with the Weddell Polynya. J. Phys. Oceanogr. 32, 1685-1698 (2002).

46. Böning, C. W., Behrens, E., Biastoch, A., Getzlaff, K. \& Bamber, J. L. Emerging impact of Greenland meltwater on deepwater formation in the North Atlantic Ocean. Nat. Geosci. 9, 523-527 (2016).

47. Spall, M. A., Almansi, M., Huang, J., Haine, T. W. N. \& Pickart, R. S. Lateral redistribution of heat and salt in the Nordic Seas. Prog. Oceanogr. 196, 102609 (2021).

48. Zhang, J. et al. Labrador sea freshening linked to Beaufort Gyre freshwater release. Nat. Commun. 12, 1229 (2021).

49. Renfrew, I. A. et al. A comparison of aircraft-based surface-layer observations over Denmark Strait and the Irminger Sea with meteorological analyses and QuikSCAT winds. Q. J. R. Meteorol. Soc. 135, 2046-2066 (2009).

50. Harden, B., Renfrew, I. \& Petersen, G. Meteorological buoy observations from the central Iceland Sea. J. Geophys. Res.: Atmospheres 120, 3199-3208 (2015).

51. Renfrew, I. et al. An evaluation of surface meteorology and fluxes over the Iceland and Greenland Seas in ERA5 reanalysis: the impact of sea ice distribution. Q. J. R. Meteorol. Soc. 147, 691-712 (2021).

52. Fairall, C. W. \& Markson, R. Mesoscale variations in surface stress, heat fluxes, and drag coefficient in the marginal ice zone during the 1983 Marginal Ice Zone Experiment. J. Geophys. Res.: Oceans 92, 6921-6932 (1987).

53. Inoue, J., Hori, M. E., Enomoto, T. \& Kikuchi, T. Intercomparison of surface heat transfer near the Arctic marginal ice zone for multiple reanalyses: A case study of September 2009. Sola 7, 57-60 (2011).

\section{Acknowledgements}

The authors would like to thank the European Centre for Medium-Range Weather Forecasts for access to the ERA5. G.W.K.M. was supported by the Natural Sciences and
Engineering Research Council of Canada. K.V. has received funding from the Trond Mohn Foundation (BFS2016REK01). I.A.R. has received funding from the Natural Environmental Research Council for the AFIS project (NE/N009754/1). R.S.P. was supported by the US National Science Foundation. This study arose from discussions during the Iceland Greenland Seas Project.

\section{Author contributions}

G.W.K.M., K.V., I.A.R, and R.S.P. jointly conceived the study. G.W.K.M. analyzed the atmospheric reanalyses and sea-ice data sets. K.V. and R.S.P. developed the current domains. All authors jointly interpreted the results and wrote the manuscript.

\section{Competing interests}

The authors declare no competing interests.

\section{Additional information}

Supplementary information The online version contains supplementary material available at https://doi.org/10.1038/s41467-021-27641-6.

Correspondence and requests for materials should be addressed to G. W. K. Moore

Peer review information Nature Communications thanks the anonymous reviewers for their contribution to the peer review of this work.

Reprints and permission information is available at http://www.nature.com/reprints

Publisher's note Springer Nature remains neutral with regard to jurisdictional claims in published maps and institutional affiliations.

(c) (i) Open Access This article is licensed under a Creative Commons Attribution 4.0 International License, which permits use, sharing, adaptation, distribution and reproduction in any medium or format, as long as you give appropriate credit to the original author(s) and the source, provide a link to the Creative Commons license, and indicate if changes were made. The images or other third party material in this article are included in the article's Creative Commons license, unless indicated otherwise in a credit line to the material. If material is not included in the article's Creative Commons license and your intended use is not permitted by statutory regulation or exceeds the permitted use, you will need to obtain permission directly from the copyright holder. To view a copy of this license, visit http://creativecommons.org/ licenses/by/4.0/.

(C) The Author(s) 2022 